\section{Lytic Enzymes for Gram-negative Bacteria Produced by Bacillus subtilis YT-25}

\section{Sawao Murao and Yoshiyuki Takahara \\ Department of Agricultural Chemistry, College of Agriculture, University of Osaka Prefecture \\ Received July 20, 1973}

Cell walls of gram-negative bacteria are complex both in morphology and in chemical composition. ${ }^{1 \sim 3}$ Many reports have been published on bacteriolytic enzymes but the vegetative cells of gram-negative bacteria are normally resistant to these enzymes., ${ }^{4}$ ) Egg white lysozyme failed to lyse gram-negative bacteria without artificial detergents ${ }^{11}$ or chelating reagents such as ethylendiamine tetraacetic acid. ${ }^{6,7)}$

Among soil bacteria which produce lytic enzymes toward Pseudomonas aeruginosa ATCC 10145, we obtained a strain YT-25 which strongly lysed the vegetative cells of gram-negative bacteria. This strain was identified as Bacillus subtilis YT-25. The lysis was caused by the combined action of lytic enzymes and a co-operating factor. This paper reports some properties of endo-Nacetylmuramidase produced by $\mathrm{YT}-25$, and the effect of the co-operating factor.

Bacillus subtilis YT-25 was aerobically grown on nutrient broth containing $0.5 \%$ glucose at $30^{\circ} \mathrm{C}$ for $30 \mathrm{hr}$. The culture filtrate of YT-25 rapidly lysed the vegetative cells of $P$. aeruginosa, Escherichia coli, Salmonella typhimurium and Klebsiella pneumoniae.

Since the lytic activity of the culture filtrate decreased with dialysis, some dialyzable cooperating factor was supposed to play an important role in the lysis of cells. The co-operating factor was purified by Amberlite IRC-50, silicic acid and Sephadex G-25 column chromatographies to almost single band in electrophoresis with polyacrylamide gel. This substance, designated as NLF (Native Cell-Lytic Factor), is heat-stable, dialyzable, soluble in methanol and has a peptide-like structure. Details of NLF will be reported in another paper.

Enzymes which lysed $P$. aeruginosa by the co-operation with NLF were then purified. The culture filtrate was applied to an Amberlite IRC-50 column and eluted by $0.5 \mathrm{M}$ sodium phosphate dibasic. After re-chromatographed on the Amberlite IRC-50 column, $P$ aeruginosa-lytic fractions were applied to a column of SP-Sephadex C-25 equilibrated with $0.1 \mathrm{M}$ acetate buffer $\mathrm{pH}$ 5.0. Linear gradient elution was performed with increasing concentration of sodium chloride from zero to $0.5 \mathrm{M}$ in the same buffer. As shown in Fig. 1, $P$. aeruginosa-lytic frac-

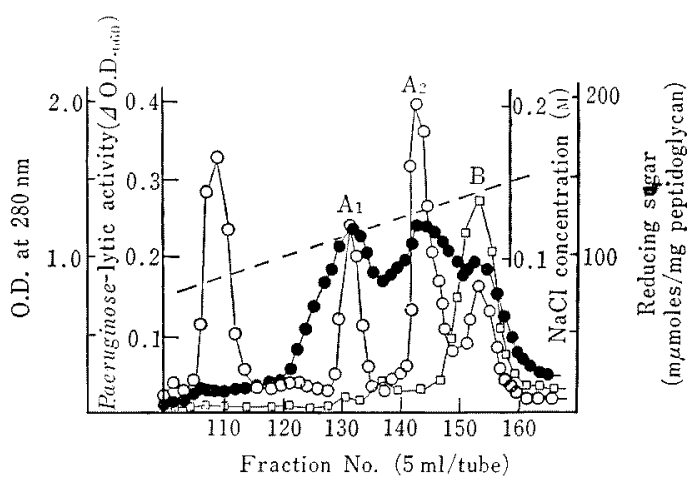

FrG. 1. Purification of Lytic Enzymes on a SP. Sephadex C-25 Column.

$P$. aeruginosa-lytic activity was estimated by measuring the decrease in optical density at $660 \mathrm{~nm}$ after incubating $2 \mathrm{ml}$ of cell suspension with $0.25 \mathrm{ml}$ of each fraction (diluted two hundred times) and $0.25 \mathrm{ml}$ of NLF solution $(0.5 \mathrm{mg} / \mathrm{ml})$ at $37^{\circ} \mathrm{C}$ for $10 \mathrm{~min}$. The cell suspension was prepared as follows: $P$. aeruginosa was cultured in nutrient broth at $37^{\circ} \mathrm{C}$ for $12 \mathrm{hr}$ on a shaker. The cells were harvested, washed with $0.01 \mathrm{M}$ Veronal- $\mathrm{HCl}$ buffer, $\mathrm{pH} 7.0$ and then suspended in the same buffer to give an optical density of 0.8 at $660 \mathrm{~m} / \mu$.

Peptidoglycan-lytic activity was estimated by measuring the increace in reducing sugar after incubating $0.1 \mathrm{ml}$ of each fraction with $0.3 \mathrm{ml}$ of $0.1 \%$ peptidoglycan at $37^{\circ} \mathrm{C}$ for $5 \mathrm{hr}$.

$\mathrm{O}-\mathrm{O}, \quad$ O.D. at $280 \mathrm{~nm} ;-\boldsymbol{- O} P$. aeruginosa-lytic activity; $\square-\square$, Peptidoglycan-lytic activity; -..-, $\mathrm{NaCl}$ concentration.

tion was separated into Fractions $A_{1}, A_{2}$ and B. Among them, only the Fraction $B$ hydrolyzed the purified peptidoglycan obtained 
from $P$. aeruginosa according to Weidel et al. ${ }^{3}$ with the release of reducing groups. The Fraction B was further purified by column chromatographies with SP-Sephadex C-25 and Sephadex G-75. The purified enzyme appeared to be homogeneous in electrophoresis with polyacrylamide gel. This enzyme was designated as B-enzyme. The purified B-enzyme failed to lyse the vegetative cells of $P$. aeruginosa, but the mixture of B-enzyme and NLF caused the lysis of $P$. aeruginosa cells as shown in Fig. 2 .

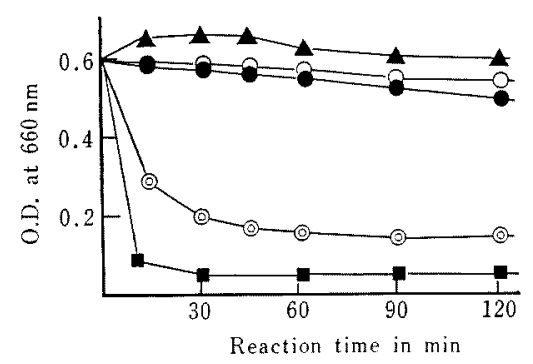

FIG. 2. Effect of NLF for Lysis of $P$. aeruginosa by B-Enzyme.

Condition for cell lysis was same as shown in Fig. 1. - - B-enzyme, final concentration was $10 \mu \mathrm{g} / \mathrm{ml}$; $\Delta-\Delta, N L F$, final concentration was $50 \mu \mathrm{g} / \mathrm{ml}$; ( ()- (e), B-enzyme, final concentration was $10 \mu \mathrm{g} / \mathrm{ml}$ and NLF, final concentration was $50 \mu \mathrm{g} / \mathrm{ml} ; \mathbf{-}-\mathbf{-}$, Culture filtrate, $0.5 \mathrm{ml}$ of the culture filtrate was added to $2 \mathrm{ml}$ of the cell suspension; $\mathrm{O}-\mathrm{O}$, Control.

The B-enzyme cleaved the purified peptidoglycan obtained from $P$. aeruginosa with the release of reducing groups but no amino terminal groups. Maximal activity on the cleavage of peptidoglycan occurred at $\mathrm{pH} 4.5$. The enzyme was stable at pH $3.5 \sim 6.0$, and the lytic activity was inhibited by various heavy metal ions but not by monoiodoacetate, $p$ chloromercuribenzoate and ethylenediamine tetraacetate.

Lysozyme-like enzymes produced by Bacillus sp. were reported as 'bacterial lysozyme'. ${ }^{8 \sim 12)}$ Enzymatic properties of 'bacterial lysozyme' were investigated in detail by Satomura et al. and Okada et al. ${ }^{12,13)}$ The B-enzyme is similar to 'bacterial lysozyme' in bacteriolytic spectrum, i.e. the B-enzyme lysed Micrococcus lysodeikticus and B. megaterium but did not
Staphylococcus aureus. However, enzymatic properties of the B-enzyme were clearly different from that of the reported 'bacterial lysozyme' in $\mathrm{pH}$ stability ${ }^{12}$ and susceptibilities to monoiodoacetate and $p$-chloromercuribenzoate. ${ }^{14)}$ These facts suggested that the B-enzyme is a new type of 'bacterial lysozyme'.

The mechanism of action of the B-enzyme on the peptidoglycan of $P$. aeruginosa was examined. Reduction of the liberated glycosidic groups with sodium borohydride according to Tipper et $a l^{15)}$ resulted in a decrease of the amount of muramic acid and only muramitol was identified as the reduction product by an automatic amino acid analyzer. These results suggested that the B-enzyme hydrolyzed the $\mathrm{N}$-acetylmuramyl-N-acetylglucosamine linkages in peptidoglycan, and caused to lyse the cells of $P$. aeruginosa.

The maximum turbidity reduction of $P$. aeruginosa suspension by the B-enzyme in the presence of NLF was inferior to that of the culture filtrate as shown in Fig. 2. This fact indicates that the other lytic substances which possess the significant action for gramnegative bacteria still remain in the culture filtrate. In fact, purified Fractions $A_{1}$ and $\mathrm{A}_{2}$ were inactive on the peptidoglycan, but remarkably lysed the vegetative cells of $P$. aeruginosa in the presence of NLF. Properties of other lytic substances are now under investigation and will be reported elsewhere.

\section{REFERENCES}

1) C. A. Schnaitman, J. Bacteriol, 108, 553 (1971).

2) V. Braun and H. Wolff, European J. Biochem., 14, 387 (1970).

3) W. Weidel, H. Frank and H. H. Martin, J. Gen. Microbiol., 22, 158 (1960).

4) J. M. Ghuysen, Bacteriol. Rev., 32, 425 (1968).

5) J. L. Strominger and J. M. Ghuysen, Science, 156, 213 (1967).

6) R. Repaske, Biochem. Biophys. Acta, 22, 189 (1956).

7) R. G. Eagon and K. J. Carson, Can. J. Microbiol, 11, 193 (1965).

8) R. A. Greenberg and H. O. Halvorson, J. Bact., 69, 45 (1955).

9) R. E. Strange and F. Dark, J. Gen. Microbiol., 
16, 236 (1957).

10) M. H. Richmond, Biochem. Biophys. Acta, 33, 78 (1959).

11) J. R. Norris, J. Gen. Microbiol., 16, 1 (1957).

12) Y. Satomura, S. Okada and J. Fukumoto, Nippon Nogeikagaku Kaishi, 31, 281 (1957).

13) S. Okada and J. Fukumoto, Nippon Nogeikagaku
Kaishi, 34, 128 (1960).

14) M. Umeda, N. Yamasaki, M. Takakuwa and S. Okada, Abstracts of Papers, Annual Meeting of Agr. Chem. Soc. Japan, April, 1973, p. 208.

15) D. J. Tipper and J. L. Strominger, Biochem. Biophys. Res. Comm., 22, 48 (1966). 